\title{
The Effect of Eight-Week Core Training Applied to High School Girls on Balance
}

\author{
Tufan Mustu ${ }^{1} \&$ H. Tolga Esen ${ }^{2}$ \\ ${ }^{1}$ Osman Nuri Yalman Anatolian High School, Mersin, Turkey \\ ${ }^{2}$ Akdeniz University, Faculty of Sport Sciences, Antalya, Turkey \\ Correspondence: H. Tolga Esen, Akdeniz University, Faculty of Sport Sciences, Physical Educationand Sports \\ Teaching Department, Antalya, Turkey. E-mail: tolgaesen@akdeniz.edu.tr
}

\author{
Received: December 22, 2019 Accepted: January 25, 2020 Online Published: January 31, 2020 \\ doi:10.5539/jel.v9n1p251 URL: https://doi.org/10.5539/jel.v9n1p251
}

\begin{abstract}
The aim of this study is to search core exercise's affect which is done regulary with female students for 8 weeks on students' balance programs. 20 volunteer female participants who were students of Osman Nuri Yalman High school (ten of them were experimental group and ten of them were control group) were included in the study. In the survey, experimental method with pretest-posttest desing was used. Core exercise was applied on experimental group three days a week during 8 weeks on the other hand no exercise was done with control group. SPSS (Ver.20) packet program was used while analyzing data statistically. Before the analysis, normality distribution was determined by being used skewness-kurtosis and hitogram and significance level was controlled according to the greenhouse-geisser and two-way repeated measures of anova values. According to the results of the survey, significant difference was found between two groups' pre-test-post-test balance values $(\mathrm{F}(2.69,48.36)$ $=42.25, \mathrm{p}<.05)$. The post-test balance values of the group in 8 directions increased significantly. When the pos-test balance values between the two groups were compared, the post- test balance values of the experimantal group participants were significantly higher than the control group participants $(\mathrm{F}(1.18)=6.20, \mathrm{p}<.05)$. Consequently; it can be said that core training applied to the high school level female students three days a week for 8 weeks can have a positive effect on balance performance.
\end{abstract}

Keywords: balance, core training, high school level

\section{Introduction}

Core is a word of English origin, meaning the core and the center of the body. The core is the midpoint of the body, including the center of gravity of the human body (Mcgill, 2010). Candron (2006) expressed the core definition as the most effective state of the spine being supported by the abdominal and spine muscles during a movement and protect this.

The core defined as whole muscles providing stability of the body in connection with the skeletal system of the trunk region (rib cage, spine, pelvis, shoulder belt), soft tissues (cartilage and connective tissues) or involving in active movements of the body (Behm et al., 2010). Exercise work is called core training performed with person's body weight, aiming to strengthen deep muscles and lumbopelvic muscles that keep the spine in balance (Atan, 2013). The body muscles are taught to control the spine during dynamic movements thanks to the core training (Takanati, 2012). Core exercises are the exercise of stabilizing muscle groups that keep the body in balance. These muscles are the hips, back and abdominal muscles. They are responsible for supporting the posture, revealing the movement, coordination of muscle action, ensuring soundness, absorption of force, revealing the force and transferring it to the whole body (Atıc1, 2013).

The ability of the body to hold the center of gravity on the resting area at minimum swing and maximum stasis is called balance (Pinar et al., 2006). The balance is the body ability to stand in a stable position, or in other words, it can make conscious movements against gravity (Kirchner, 2001). The coordination of mainly muscular activity, including the preservation of the posture is called balance. Balance is the mechanism by which the human body protects itself against falling (Winter, 1995).

The balance is divided into dynamic and static. The ability of the body to move to balance in motion is defined as dynamic balance (Arslanoğlu et al., 2010). Dynamic balance includes walking, weight-transferring movements, 
step up and down, sitting-up and different kinds of daily life and the integration between these movements (Chaudhari \& Andriachi, 2006). Static balance is defined as the balance that is provided automatically to maintain the general posture or body parts in a certain position on a fixed support surface and without the need for any external force (Nichols et al., 1995). Some studies show that core training positively affects balance. Kahle (2009) expressed that balance can be achieved more easily by strengthening of the muscles which are mostly associated with spine control thanks to the core training in his thesis.

Lehman et al. (2005), in their study stated that the ball with the core training proprioceptors improved balance ability and positive development of the participants in situations requiring balance in daily life. Aggarwal et al. (2010) investigated the effect of core and balance training on static and dynamic balance performance. As a result, it was stated that the dynamic balance developed in a positive direction, in addition, the effect of core training on static balance was more than balance training.

\section{Method}

\subsection{Research Group}

This research was carried out on 10 female students (experimental group) and 10 female students (control group) aged 15-17 years who were chosen by random sampling method in Osman Nuri Yalman Anatolian High School in Mut, Mersin. The research was carried out in the form of an experimental study model with pre-test and post-test design in order to examine the balance development levels as a result of a core training program.

\subsection{Data Collection}

In this study, the students of the experimental group received a core training program for 3 days a week (Monday-Wednesday-Friday) for 8 weeks while control group female students received nothing. Star balance test was used to determine students' balance development.

\subsection{Star Balance Test}

Star balance tests are functional tests involving one leg posture on one leg with maximum reach of the other leg. The star balance test is carried out with a grid of 8 lines placed at a 45-degree angle on the ground. The 8 lines positioned on the grid are named according to the orientation directions such as anterolateral, anterior, anteromedial, medial, posteromedial, posterior, posterolateral, and lateral.The grid was drawn on a hard tile floor in the indoor gym, using a 3 meter $(7.62 \mathrm{~cm})$ wide adhesive tape in a square frame of $182.9 \mathrm{~cm} \times 182.9 \mathrm{~cm}$ (Hertel et al., 2000). An oral and visual representation of the test procedure was given to each subject by the researcher. Hertel et al. (2000), as suggested by each subject, performed 6 practice trials in 8 different directions for each leg. After practice, each subject ran for 5 minutes at his/her own pace and stretched the quadriceps, hamstrings and triceps muscle groups before the test. To perform the star balance test, the subject maintained a one-leg posture while extending the reach leg to the maximum point along the meter in any direction. The subject gently touched the furthest point on the meter with the most extreme part of the access foot. The subject was instructed to reach the farthest point on the line and make a light touch to ensure that the balance is achieved with adequate neuromuscular control of the posture leg. The subject then returned to the initial posture, maintaining the balance. Measurements were taken by the same researcher after each access (Hertel et al., 2000). 6 attempts were made for one-star balance test score of each participant. Subjects were given 15 seconds to rest between access. The average of the 3 best accesses of each leg in 8 directions was calculated. The access leg (right, left), the order of trips (clockwise, counterclockwise), and the direction of the first trip (Anterior, Medial, Lateral, Posterior) are balanced to be controlled for any learning or pattern effects. Then all trials were performed counter clockwise or clockwise sequentially (Hertel et al., 2000). While subjects maintaining their position on the posture leg; did not touch the line with the access foot, posture foot raised from the center of the grill, lost balance at any point in the trial, trials were repeated in cases where initial and return did not continue. The trial was canceled when the investigator found that the subject had lowered the access foot to the floor to significantly support the body. No subject reported fatigue during or after the test session (Hertel et al., 2000). The lengths of the participants were measured with a portable calibrator with a precision of $\pm 1 \mathrm{~mm}$ and capacity of 20-205 cm. Length of the subjects; measured after taking position of anatomical posture, barefoot and toe heels combined, head frontal plane, above the head plate vertex point and values are recorded in 'cm' (Sever, 2013). The weights of the participants were measured with a sinbo SBS-4445 digital scale with a precision of $\pm 100 \mathrm{gr}$ and a capacity of $180 \mathrm{~kg}$. The participants went to the scale with their bare feet and shorts. In the measurement of leg lengths, the participants were laid on a flat surface with their feet united and bare feet. The tape measure was fixed to the floor by the participant's right heel and the tape was extended to the point where the pelvis ended and the result was recorded as the participant's leg length. 


\subsection{Training Program (Brungardt et al., 2006)}

Table 1. 1st week training details

\begin{tabular}{llll}
\hline WEEK & MOVEMENT & SET/TIME & REST BREAK \\
\hline 1st week & 1) Plank & $3 \times 35 \mathrm{sec}$ & $40 \mathrm{sec}$ \\
& 2) Side Plank (right elbow on floor) & $3 \times 30 \mathrm{sec}$ & $35 \mathrm{sec}$ \\
& 3) Side Plank (left elbow on floor) & $3 \times 30 \mathrm{sec}$ & $35 \mathrm{sec}$ \\
& 4) Opposite Arm and Leg- All Fours (right leg-left arm) & $3 \times 30 \mathrm{sec}$ & $35 \mathrm{sec}$ \\
5) Opposite Arm and Leg- All Fours (left leg-right arm) & $3 \times 30 \mathrm{sec}$ & $35 \mathrm{sec}$ \\
6) Double Side Jackknife (on the right arm) & $3 \times 25 \mathrm{sec}$ & $30 \mathrm{sec}$ \\
7) Double Side Jackknife (on the left arm) & $3 \times 25 \mathrm{sec}$ & $30 \mathrm{sec}$ \\
8) Glute Bridge & $3 \times 50 \mathrm{sec}$ & $40 \mathrm{sec}$ \\
\hline
\end{tabular}

Table 2. 2-3rd week training details

\begin{tabular}{llll}
\hline WEEK & MOVEMENT & SET/TIME & REST BREAK \\
\hline 2-3rd week & 1) Plank & $3 \times 40 \mathrm{sec}$ & $40 \mathrm{sec}$ \\
& 2) Up Plank- Flutters (each set different legs) & $6 \times 25 \mathrm{sec}$ & $30 \mathrm{sec}$ \\
& 3) Balance Hold & $6 \times 30 \mathrm{sec}$ & $30 \mathrm{sec}$ \\
& 4) Plank Swimming (You should use different arm and leg in each set) & $6 \times 30 \mathrm{sec}$ & $35 \mathrm{sec}$ \\
\hline 5) Russian Twists & & \\
\hline
\end{tabular}

Table 3. 4th week training details

\begin{tabular}{llll}
\hline WEEK & MOVEMENT & SET/TIME & REST BREAK \\
\hline 4th week & 1) Up Plank- Flutters (each set different foot) & $6 \times 25 \mathrm{sec}$ & $30 \mathrm{sec}$ \\
& 2) Balance Hold & $6 \times 35 \mathrm{sec}$ & $30 \mathrm{sec}$ \\
& 3) Bent- Leg Kickbacks (You should use different leg in each set) & $6 \times 15 \mathrm{repeat}$ & $25 \mathrm{sec}$ \\
& 4) Glute Bridge, Single Leg Rotation (each set different foot) & $6 \times 30 \mathrm{sec}$ & $30 \mathrm{sec}$ \\
\hline 5) Russian Twists & & \\
\hline
\end{tabular}

Table 4. 5th week training details

\begin{tabular}{llll}
\hline WEEK & MOVEMENT & SET/TIME & REST BREAK \\
\hline 5th week & 1) Up Plank- Flutters (each set different foot) & $6 \times 25 \mathrm{sec}$ & $30 \mathrm{sec}$ \\
& 2) Balance Hold & $6 \times 35 \mathrm{sec}$ & $30 \mathrm{sec}$ \\
& 3) Plank Swimming (You should use different arm and leg in each set) & $6 \times 15 \mathrm{sec}$ & $35 \mathrm{sec}$ \\
4) Bent-Leg Kickbacks (You should use different leg in each set) & $6 \times 15 \mathrm{repeat}$ & $25 \mathrm{sec}$ \\
& 5) Glute Bridge, Single Leg Rotation (each set different foot) & $6 \times 30 \mathrm{sec}$ & $30 \mathrm{sec}$ \\
\hline
\end{tabular}

Table 5. 6th week training details

\begin{tabular}{llll}
\hline WEEK & MOVEMENT & SET/TIME & REST BREAK \\
\hline 6th week & 1) Plank & $3 \times 35 \mathrm{sec}$ & $40 \mathrm{sec}$ \\
& 2) Up Plank- Flutters (each set different foot) & $6 \times 25 \mathrm{sec}$ & $30 \mathrm{sec}$ \\
3) Balance Hold & $6 \times 35 \mathrm{sec}$ & $30 \mathrm{sec}$ \\
4) Plank Swimming (You should use different arm and leg in each set) & $6 \times 15 \mathrm{sec}$ & $35 \mathrm{sec}$ \\
5) Bent-Leg Kickbacks (You should use different leg in each set) & $6 \times 15 \mathrm{repeat}$ & $25 \mathrm{sec}$ \\
6) Glute Bridge, Single Leg Rotation (each set different foot) & $6 \times 30 \mathrm{sec}$ & $30 \mathrm{sec}$ \\
7) Russian Twists & & \\
\hline
\end{tabular}

Table 6.7-8th week training details

\begin{tabular}{|c|c|c|c|}
\hline WEEK & MOVEMENT & SET/TIME & REST BREAK \\
\hline \multirow[t]{6}{*}{$7-8$ th week } & 1) Up Plank- Flutters (each set different foot) & $6 \times 25 \mathrm{sec}$ & $30 \mathrm{sec}$ \\
\hline & 2) Balance Hold & $6 \times 35 \mathrm{sec}$ & $30 \mathrm{sec}$ \\
\hline & 3) Bent-Leg Kickbacks (You should use different leg in each set) & $6 \times 15$ repeat & $25 \mathrm{sec}$ \\
\hline & 4) Glute Bridge, Single Leg Rotation (each set different foot) & $6 \times 30 \mathrm{sec}$ & $30 \mathrm{sec}$ \\
\hline & 5) Glute Bridge & $3 \times 50 \mathrm{sec}$ & $40 \mathrm{sec}$ \\
\hline & 6) Russian Twists & & \\
\hline
\end{tabular}




\subsection{Analysis of the Data}

ANOVA test was used for 2 (group) $x 8$ (direction) mixed measurements. This analysis was chosen to determine the difference between the pre-test and post-test tests of the two groups and to check whether there was a significant difference between the groups (Tabachnick \& Fidell, 2012). Homogeneity, normal distribution and independent observation assumptions were checked before analysis. The normal distribution assumption was checked using skewness-kurtosis and histogram. According to the findings, the data showed normal distribution. Levene's test was checked for homogeneity and a homogeneous distribution assumption was provided based on the data obtained in 8 directions. The final assumption, the independent observation assumption is provided for this test. It was decided to check the significance level according to the Greenhouse-Geisser and Two-Way Repeated Measures of Anova values.

\section{Findings}

The ages of the groups participated in the study: experimental group $15.50 \pm 0.70$, control group $15.10 \pm 0.87$, average length: experimental group $163 \pm 6.18 \mathrm{~cm}$, control group $162.2 \pm 6.47 \mathrm{~cm}$, weight averages: experimental group $51.7 \pm 6.58 \mathrm{~kg}$, control group $49.6 \pm 6.60 \mathrm{~kg}$ and mean leg length: experimental group $90.2 \pm$ $4.36 \mathrm{~cm}$, the control group was $91.7 \pm 3.23 \mathrm{~cm}$.

Table 7. Pre-test-post-test results between experimental and control groups

\begin{tabular}{lllll}
\hline & $\boldsymbol{d} \boldsymbol{f}$ & Average Square & $\boldsymbol{F}$ & Sig. \\
\hline Group & 1 & 2178.83 & 6.20 & $\mathbf{. 0 2}$ \\
Mistake & 18 & 351.67 & & \\
\hline
\end{tabular}

Table 7 shows the results of the analysis to check whether there is a significant difference between the groups. According to the findings, a significant difference was found between the experimental group and the comparison group $(\mathrm{F}(1.18)=6.20 . \mathrm{p}<.05)$. According to the results, the post-test values of the experimental group participants were significantly higher than the control group participants.

Table 8. Two-way repeated measures of Anova Test results of different directions between experimental and control groups

\begin{tabular}{|c|c|c|c|c|}
\hline & $d f$ & Average square & $F$ & Sig. \\
\hline Anterior Front & 1 & 144.29 & 2.66 & .12 \\
\hline \multicolumn{5}{|l|}{ Anterior End } \\
\hline Anteriomedial Front & 1 & 125.14 & 3.76 & .07 \\
\hline \multicolumn{5}{|l|}{ Anteriomedial End } \\
\hline Medial Front & 1 & 105.79 & 3.79 & .07 \\
\hline \multicolumn{5}{|l|}{ Medial End } \\
\hline Posteriomedial Front & 1 & 433.95 & 6.23 & .02 \\
\hline \multicolumn{5}{|l|}{ Posteriomedial End } \\
\hline Posterior Front & 1 & 483.03 & 6.99 & .02 \\
\hline \multicolumn{5}{|l|}{ Posterior End } \\
\hline Posteriolateral Front & 1 & 370.58 & 3.27 & .09 \\
\hline \multicolumn{5}{|l|}{ Posteriolateral End } \\
\hline Lateral Front & 1 & 348.10 & 3.22 & .09 \\
\hline \multicolumn{5}{|l|}{ Lateral End } \\
\hline Anteriolateral Front & 1 & 222.08 & 4.19 & .06 \\
\hline Anteriolateral End & & & & \\
\hline
\end{tabular}

Table 8 shows the pre-test and post-test balance values between the experimental and control groups. As a result of the analysis, a significant difference was found between the pre-test and post-test balance scores of the experimental and control groups only in the posteriomedial $(\mathrm{p}<0.05)$ and posterior $(\mathrm{p}<0.05)$ directions.

\section{Discussion}

Although human beings provide natural processes such as rotation, sitting, crawling, standing, running, jumping from the birth with the natural development of balance, the current balance performance of the person does not spontaneously reach the maximal point without a physical activity, a sports branch or any activity affecting the 
balance. As a matter of fact, some studies support the positive effect of core training on balance development.

In a study conducted by Sadeghia et al. (2013) stated that dynamic postural control was developed in volleyball players strengthening the core region. When Sadeghia et al. compared pre-test and post-test results of volleyball players, they found improvement in balance in the posteriolateral, posterior, posteriomedial and medial directions of the right and left legs. Atıc1 (2013) stated that the regular core training performed for 8 weeks and 3 days a week had a significant effect on balance performances in women between 18-24 years of age. Yüksel et al. (2016) examined the effect of basketball players on lower extremity strength training on dynamic balance and there was an improvement in dynamic balance in aspects lateral, posteriolateral, posterior, posteriomedial, medial, anteriomedial directions for the left foot and posteriolateral, posterior, posteriomedial, medial directions for the right foot and consequently, core training increased dynamic balance efficiency.

In this study, the balance performances of high school students were examined as a result of the 8-week core study. When the posttest scores between the experimental and control groups were compared, a significant difference was found between the experimental group and the control group $\left(\mathrm{F}_{(1.18)}=6.20, \mathrm{p}<.05\right)$. According to the results, the post-test values of the experimental group participants were significantly higher than the control group participants. When the pre-test and post-test balance scores between the experimental and control groups were examined, there was a significiant difference only in posteriomedial and posterior directions $(\mathrm{p}<0.05)$. Rahmat et al. $(2012)$ stated that 6 -week core training with mentally retarded students improved the dynamic balance. Cosio-Lima et al. (2003) compared core stability and balance training with traditional training, reported a 5-week workout with pilates ball improved stability of the core and balance groups. Axel (2013) applied 8 weeks of core training to 19 surfing athletes with an average age of 15 years and examined the differences between the pre-test post-test measurements of the motoric characteristics of athletes. As a result, a statistically significant difference was found between pre-test and post-test measurement values of the motor skills of the athletes, core training had a positive effect on balance ability. Biyıklı (2018) examined the effects of 10-week core training on physical performance in female swimmers aged 11-13 and stated that core training appropriate to age in adolescence or before adolescence had a positive contribution on balance. Samson (2005) examined the effect of core training on dynamic balance in his study on tennis athletes. As a result of the five-week core training, he observed a positive improvement in the dynamic balance characteristic of the experimental group.

Dilber et al. (2016) investigated the effect of 8 -week core training on performance-related physical fitness variables in male football players, as a result of the 8-week core program, a significant difference was found between pre-test and post-test balance values of male football players in favor of post-test. He stated that training improved balance. Granacher et al. (2013) investigated the importance of trunk muscle strength for balance, functional performance and fall prevention in the elderly, as a result, he stated that a stable and strong core region make lower and upper extremities be used more efficiently, may contribute to increase in balance and functional performance in elderly.

According to these results; It can be said that regular, structured and planned core training for 8 weeks of high school level girls who have a sedentary life has a positive effect on improving their balance skills.

\section{References}

Aggarwal, A., Kumar, S., Kalpana, Z., Jitender, M., \& Sharma, V. P. (2010). The Relationship Between Core Stability Performance And The Lower Extremities Static Balance Performance In Recreationally Active Indıviduals. Nigerian Journal of Medical Rehabilitation, 15(1), 11-16.

Arslanoğlu, E., Arslanoğlu, C., Aydoğmuş, M., \& Şenel, Ö. (2010). Badmintoncularda reaksiyon zamanı ve denge ilişkisi. Beden Eğitimi ve Spor Bilimleri Dergisi, 4(2), 132-133.

Atan, T., Kabadayı, M., Elıoz, M., C1lhoroz, B. T., \& Akyol, P. (2013). Effect of jogging and core training after supramaximal exercise on recovery. Turkish Journal of Sport and Exercise, 15(1), 73-77.

Atıcı, M. (2013). Yüzme sporu yapan 18-24 yaş arası kadınlarda core antrenmanın bazı fizyolojik ve motorik parametrelere etkisinin araştırılması. Muğla Sitkı Koçman Üniversitesi Sağlık Bilimleri Enstitüsü Beden Eğitimi ve Spor Anabilim Dalı. Yüksek Lisans Tezi. Muğla.

Axel, T. A. (2013). The effects of a core strength training program on field testing performance outcomes in junior elite surf athletes. California State University. Master thesis. California.

Behm, D. G., Drinkwater, E. J., Willardson, J. M., \& Cowley, P. M. (2010). The use of instability to train the core musculature. Applied Physiology Nutrition and Metabolism, 35(1), 91-108. https://doi.org/10.1139/H09-127

Bıyıklı, T. (2018). 10 Haftalık kor antrenmanın 11-13 yaş arası kız yüzücülerde fiziksel performansa etkisi. Sportif 
Bakış: Spor ve Eğitim Bilimleri Dergisi, 5(2), 81-91.

Bressel, E., Yonker, J. C., Kras, J., \& Heath, E. M. (2007). Comparison of static and dynamic balance in female collegiate soccer. basketball. and gymnastics athletes. Journal of Athletic Training, 42(1), 42-46.

Brungardt, K., Brungardt, B., \& Brungardt, M. (2006). The complete book of core tarıning. New York: Hyperion publications.

Chaudhari, A. M., \& Andriacchi, T. P. (2006). The mechanical consequences of dynamic frontal plane limb aligment for non-contact acl injury. Journal of Biomechanics, 39(2), 330-338. https://doi.org/10.1016/j.jbiomech.2004.11.013

Condron, D. (2006). Swiss Ball and Core Workout. New York.

Cosio-Lima, L. M., Reynolds, K. L., Winter, C., Paolone, V., \& Jones, M. T. (2003). Effects of physioball and conventional floor exercises on early phase adaptations in back and abdominal core stability and balance in women. The Journal of Strength \& Conditioning Research, 17(4), 721-725. https://doi.org/10.1519/00124278-200311000-00016

Dilber, O. A., Lağap, B., Akyüz, Ö., Çoban, C., Akyüz, M., Taş, M., Akyüz, F., \& Özkan, A. (2016). Erkek Futbolcularda 8 haftalık kor antrenmanının performansla ilgili fiziksel uygunluk değişkenleri üzerine etkisi. CBÜ Beden Eğitimi ve Spor Bilimleri Dergisi, 11(2), 77-82.

Granacher, U., Gollhofer, A., Hortobagyi, T., Kressig, W. R., \& Muehlbauer, T. (2013). The importance of trunk muscle strength for balance, functional performance, and fall prevention in seniors: A systematic review. Sports Med, 43(1), 627-641. https://doi.org/10.1007/s40279-013-0041-1

Hertel, J., Miller, S. J., \& Denegar, C. R. (2000). Intratester and intertester reliability during the star excursion balance tests. Journal of Sport Rehabilitation, 9(2), 104-116. https://doi.org/10.1123/jsr.9.2.104

Kahle, N. (2009). The effects of core stability training on balance testing in young. healthy adults. The University of Toledo. As Partial Fulfillment of The Requirements For The Bachelor of Science degree with Honors in Exercise Science. Spain. https://doi.org/10.3928/19425864-20090301-03

Kirichner, G. (2001). Physical education for elementary school children (pp. 30-31). Brown Publishers Lowa. ABD.

Lehman, G., Gordon, T., Langley, J., Pemrose, P., \& Tregaskis, S. (2005). Replacing a swiss ball for an exercise bench causes variable changes in trunk muscle activity during upper limb strength exercises Dynamic. Medicine, 4(1), 1-2. https://doi.org/10.1186/1476-5918-4-6

Mcgill, S. (2010). Core training: Evidence translating to better performance and injury prevention. J. Strength Cond Res., 32(3), 33-46. https://doi.org/10.1519/SSC.0b013e3181df4521

Nichols, D. S., Glenn, T. M., \& Hutchınson, K. J. (1995). Changes in themeancenter of balance during balance testingin youngadults. Journal of the American Physical Therapy, 75(8), 699-706. https://doi.org/10.1093/ptj/75.8.699

Pınar, S., Tavacıŏlu, L., \& Atılgan, O. E. (2006). Dansçılarda denge becerileri ile İlgili olabilecek faktörlerin incelenmesi (pp. 259-261). 9. Spor Bilimleri Kongresi Muğla.

Rahmat, A., Daneshmandi, H., \& Barati, A. H. (2012). The effect of 6 weeks core stabilization training program on the balance in mentally retarded students. International Journal of Sport Studies, 10(2), 496-501.

Sadeghi, H., Shariat, A., Asadmanesh, E., \& Mosavat, M. (2013). The effeccts of core stability exercise on the dynamic bakance of voleyball players. International Journal of Applied Execies Physiology, 2(2), 1-10.

Samson, K. M. (2005). The effects of a five-week core stabilization-training program on dynamic balance in tennis athletes. West Virginia Univ. Master Thesis. Virginia.

Sever. O. (2013). Futbolcuların fiziksel uygunluk düzeylerinin mevki ve yaş değişkenlerine göre incelenmesi. Gazi Üniversitesi Sağlık Bilimleri Enstitüsü Beden Eğitimi ve Spor Anabilim Dalı. Yüksek Lisans Tezi. Ankara.

Tabachnick, B. G., \& Fidell, L. S. (2012). Using Multivariate Statistics (6th ed.). Allyn \& Bacon/Pearson Education.

Winter, D. A. (1995). Human balance and posture control during standing and walking. Gait and Posture, 3(1), 193-214. https://doi.org/10.1016/0966-6362(96)82849-9 
Yüksel, O., Akkoyunlu, Y., Karavelioğlu, M., Harmancı, H., Kayhan, M., \& Koç, H. (2016). Basketbolcularda core alt ekstremite kuvveti antrenmanlarının dinamik denge ve şut isabeti üzerine etkisi. Marmara Üniversitesi Spor Bilimleri Dergisi, 1(1), 54-55. https://doi.org/10.22396/sbd.2016.5

\section{Copyrights}

Copyright for this article is retained by the author, with first publication rights granted to the journal.

This is an open-access article distributed under the terms and conditions of the Creative Commons Attribution license (http://creativecommons.org/licenses/by/4.0/). 